\title{
Protein Excretion Rate
}

National Cancer Institute

\section{Source}

National Cancer Institute. Protein Excretion Rate. NCI Thesaurus. Code C150822.

A determination of the amount of total protein being excreted in a biological specimen over a defined period of time. 